\title{
PELAKSANAAN PROGRAM PERKESMAS DI PUSKESMAS KOTA BENGKULU
}

\author{
Hermansyah, Agung Riyadi, Ratna Dewi \\ Politeknik Kesehatan Kementerian Kesehatan Bengkulu, Jurusan Keperawatan dan Kebidanan, \\ Jalan Indragiri Nomor 03 Padang Harapan Bengkulu \\ man2aditya@yahoo.com
}

\begin{abstract}
Public Health Care activities in Bengkulu city were only well implemented in Ratu Agung Public Health Center, Padang Serai Public Health Center, Beringin Raya Public Health Center, and Betungan Public Health Center. Public Health Center is regularly sent statements. There are 8751 households vulnerable in the city of Bengkulu, and 500 families who have fostered $(5.71 \%)$. The purpose of this research was to determine the factors associated with the implementation of public health care in Bengkulu City. The type of this research was analytic cross-sectional design. The research population were public health care's nurse managers in 20 public health centers in Bengkulu city, amounting 24 people. Samples were taken with a total sampling technique. Data were collected by using questionnaires and observation guidelines. The data were analyzed using univariate, bivariate analysis using Pearson product moment correlation test and chi-square. The results showed that almost half (45.8\%) of respondents stated public health care implementation in public health centers were less category. The bivariate analysis showed that the independent variables associated with the implementation of public health center activities in Bengkulu city were variables of planning ( $p$ $=0.025)$ and control variables $(\mathrm{p}=0.014)$, whereas the variables of training, knowledge, attitude, skill, organization, and mobilization/implementation were not connected. To improve the implementation of public health care activities in public health centers in Bengkulu city, Health Office should requires all public health center leaders implementing the good planning functions and control the human resource of nurse managers.
\end{abstract}

Keywords : training, competency, management functions, implementation of public health care

\begin{abstract}
Abstrak : Kegiatan perkesmas di Kota Bengkulu baru dilaksanakan dengan baik di Puskesmas Ratu Agung, Puskesmas Padang Serai, Puskesmas Beringin Raya, dan Puskesmas Betungan. Puskesmas tersebut rutin mengirimkan laporan. Terdapat $8.751 \mathrm{KK}$ rawan di Kota Bengkulu, dan $500 \mathrm{KK}$ yang telah dibina $(5,71 \%)$. Tujuan penelitian ini adalah mengetahui faktor-faktor yang berhubungan dengan pelaksanaan kegiatan perkesmas di Puskesmas Kota Bengkulu. Jenis Penilitian ini adalah Analitik dengan rancangan cross-sectional. Populasi penelitian adalah perawat pengelola perkesmas di 20 Puskesmas Kota Bengkulu yang berjumlah 24 orang. Sampel penelitian diambil dengan teknik total sampling. Pengumpulan data dilakukan dengan menggunakan kuesioner dan pedoman observasi. Analisis data dilakukan secara univariat, analisis bivariat dengan menggunakan uji korelasi pearson product moment dan chi-square. Hasil penelitian menunjukkan bahwa hampir sebagian $(45,8 \%)$ responden menyatakan pelaksanaan perkesmas di Puskesmas dengan kategori kurang. Dari analisis bivariat diperoleh bahwa variabel independen yang berhubungan dengan pelaksanaan kegiatan perkesmas di Puskesmas Kota Bengkulu adalah variabel perencanaan $(\mathrm{p}=0,025)$ dan pengendalian $(\mathrm{p}=0,014)$, sedangkan variabel pelatihan, pengetahuan, sikap, keterampilan, pengorganisasian, dan penggerakan/pelaksanaan tidak berhubungan. Untuk meningkatkan pelaksanaan kegiatan perawatan kesehatan masyarakat di Puskesmas kota Bengkulu, Dinas Kesehatan harus mewajibkan seluruh pimpinan puskesmas untuk menerapkan fungsi pengendalian SDM terhadap perawat pengelola perkesmas
\end{abstract}

Kata Kunci : Pelatihan, kompetensi, fungsi manajemen, pelaksanaan perkesmas

Sasaran perkesmas adalah individu, keluarga, dan kelompok yang mempunyai masalah kesehatan akibat faktor ketidaktahuan, ketidamauan, maupun ketidakmampuan 
dalam menyelesaikan masalah kesehatannya. Prioritas sasaran adalah individu, keluarga, kelompok dan masyarakat yang mempunyai masalah kesehatan dengan memprioritaskan daerah yang belum terjangkau dengan sarana pelayanan kesehatan atau sudah memanfaatkan tetapi memerlukan tindak lanjut. Fokus utama pada keluarga rawan kesehatan, yaitu keluarga miskin yang rentan dan keluarga yang termasuk resiko tinggi (Depkes RI, 2006). Keluarga yang tidak mendapat pelayanan perkesmas merupakan beban sosial dan ekonomi serta berdampak buruk terhadap masyarakat lainnya. Pemerintah memiliki tanggung jawab melindungi kesehatan masyarakat dan memberikan hambatan untuk mencapai pusat-pusat pelayanan kesehatan .

Kegiatan perawat perkesmas dapat terwujud malalui peningkatan kerjasama lintas program terkait. Pelaksanaan perkemas melalui program kesehatan wajib seperti program Kesehatan Ibu dan Anak (KIA) serta Pemberantasan penyakit Menular (P2M) dapat dilakukan melalui kegiatan imunisasi. Petugas puskesmas dapat mendatangi keluarga untuk melakukan pembinaan pada bayi yang drop out (DO). (Depkes RI, 2006).

Kegiatan Perkesmas di Provinsi Bengkulu juga belum menunjukkan hasil yang menggembirakan sejak diaktifkan kembali pada tahun 2012. Dari 180 Puskesmas yang ada hanya 42 Puskesmas yang melaksanakan kegiatan perkesmas dengan baik, yaitu 4 Puskesmas di Kota Bengkulu, 3 Puskesmas di Kabupaten Muko-muko, 5 Puskesmas di Kabupaten Bengkulu Utara, 4 Puskesmas di Kabupaten Rejang Lebong, 4 Puskesmas di Kabupaten Kepahiang, 4 Puskesmas di Kabupaten Kaur, 5 Puskesmas di Kabupaten Lebong, 5 Puskesmas di Kabupaten Bengkulu Selatan, 3 Puskesmas di Kabupaten Seluma, dan 5 Puskesmas di Kabupaten Bengkulu Tengah (Dinkes Provinsi Bengkulu, 2014).

Hasil wawancara dengan kasie pelayanan Kesehatan Dasar Dinkes Provinsi Bengkulu, didapatkan bahwa banyak penyebab kegiatan perkesmas tidak berjalan dengan baik di beberapa Puskesmas Provinsi Bengkulu antara lain perawat belum dilatih program perkesmas, PHN kit tidak ada, masyarakat tidak aktif/tidak merespon program dengan baik, kemampuan perawat dan dukungan kepala Puskesmas yang kurang. Hasil penelitian Nurhomah (2013) di desa Imigrasi Permu Puskesmas Nanti Agung Kabupaten Kepahiang, menunjukkan bahwa 37,8\% kepala keluarga kurang aktif mengikuti kegiatan perkesmas.

Kegiatan perkesmas di Kota Bengkulu baru dilaksanakan dengan baik di Puskesmas Ratu Agung, Puskesmas Padang Serai, Puskesmas Beringin Raya, dan Puskesmas Betungan, dimana Puskesmas tersebut rutin mengirimkan laporan. Dari $8.751 \mathrm{KK}$ rawan di Kota Bengkulu baru $500 \mathrm{KK}$ yang menjadi binaan (5,71\%). Puskesmas Ratu Agung mempunyai 33 KK Rawan yang dibina 32 KK, Puskesmas Padang Serai 40 KK Rawan yang dibina $40 \mathrm{KK}$, Puskesmas Beringin Raya 507 KK yang dibina $24 \mathrm{KK}$, dan Puskesmas Betungan $40 \mathrm{KK}$ yang dibina $2 \mathrm{KK}$ (Dinkes Provinsi Bengkulu, 2014).

Banyak faktor yang mempengaruhi pelaksanaan kegiatan perkesmas, diantaranya adalah petugas kesehatan dan pengelolaan perkesmas. Kesehatan dipengaruhi oleh dua faktor pokok yaitu faktor perilaku (behavior causes) dan non perilaku (non behavior causes). Faktor perilaku khususnya perilaku kesehatan ditentukan oleh tiga faktor. Pertama, faktor predisposisi (predispocing factor) yang terwujud dalam pengetahuan, sikap, kepercayaan, nilai-nilai dan sebagainya. Kedua, faktor pendukung (enabling factor) yang terwujud dari lingkungan fisik seperti tersedia atau tidaknya fasilitas kesehatan. Ketiga, faktor pendorong (reinforcing factor) yang terwujud dalam sikap dan perilaku keluarga, masyarakat, pimpinan, petugas kesehatan, dan lainnya Green, et al (1980, dalam Notoatmodjo, 2010).

Salah satu faktor dominan yang berhubungan dengan kinerja perawat peskesmas dalam melaksanakan perkesmas adalah faktor kemampuan petugas Pitoyo (2000) dalam Septiano \& Hasan Basri (2007). Kemampuan perawat sangat diperlukan dalam mendukung tujuan yang hendak dicapai dari pelaksanaan 
perkesmas. Kemampuan petugas terdiri dari pengetahuan, sikap dan keterampilan (Tafwidhah, 2010).

Pengelolaan perkesmas sangat berperan penting dalam pelaksanaan perkesmas. Pengelolaan tersebut sangat berkaitan erat dengan sistem yang digunakan sebagai acuan nasional dalam pelaksanaan perkesmas. Pelaksanaan perkesmas saat ini tengah diintegrasikan dengan sistem Pengembangan Manajemen Kinerja (PMK) untuk perawat (Kemenkes, 2011). Seharusnya sesuai dengan program perkesmas yang dijalankan secara nasional, apalagi Pus-kesmas telah terpapar mengenai PMK, pelaksanaan perkesmas itu berdasarkan implementasi program PMK. Sehingga integrasi perkesmas dengan PMK akan bersinergi baik dan menghasilkan pencapaian perkesmas sesuai yang diharapkan (Ratnasari, 2012).

Hasil penelitian di Dinkes Hulu Sungai Tengah menunjukkan bahwa terdapat hubungan yang signifikan antara fungsi manajemen perencanaan $(\mathrm{p}=0,016)$, pengorganisasian $(\mathrm{p}=0,019)$, pelaksanaan $(\mathrm{p}=0,020)$, pengarahan $\quad(\mathrm{p}=0,022)$, pengendalian $(\mathrm{p}=0,020)$, penilaian $(\mathrm{p}=0,019)$, dengan cakupan program perkesmas (Hernadi, 2005). Penelitian ini bertujuan mengetahui faktorfaktor yang berhubungan dengan pelaksanaan kegiatan perkesmas di Puskesmas Kota Bengkulu.

\section{BAHAN DAN CARA KERJA}

Penelitian ini menggunakan rancangan cross-sectional. Populasi adalah perawat yang melaksanakan kegiatan perkesmas di 20 Puskesmas Kota Bengkulu yang berjumlah 24 orang perawat. Sampel penelitian diambil dengan teknik total sampling terhadap seluruh populasi. Pengumpulan data dilakukan dengan menggunakan kuesioner, pedoman observasi, dan wawancara. Analisis data dilakukan secara univariat untuk melihat distrubusi frekuensi masing-masing variabel penelitian, dan analisis bivariat dengan menggunakan uji chisquare pada $\alpha 5 \%$
HASIL

Analisis Univariat

Tabel 1 Karakteristik Responden

\begin{tabular}{|c|c|c|c|}
\hline Variabel & Kategori & $\begin{array}{l}\text { Frekuensi } \\
\text { (f) }\end{array}$ & $\begin{array}{c}\text { Prosentase } \\
(\%)\end{array}$ \\
\hline \multicolumn{4}{|c|}{ Karakteristik $(\mathrm{n}=24)$} \\
\hline \multirow[t]{2}{*}{ Umur } & $\leq 30$ tahun & 14 & 58,3 \\
\hline & $>30$ tahun & 10 & 41,7 \\
\hline \multirow[t]{2}{*}{ Jenis Kelamin } & Laki-laki & 4 & 16,7 \\
\hline & Perempuan & 20 & 83,3 \\
\hline \multirow[t]{3}{*}{ Pendidikan } & DIII Keperawatan & 13 & 54,2 \\
\hline & DIV Keperawatan & 2 & 8,3 \\
\hline & S.Kep/Ners & 9 & 37,5 \\
\hline \multirow[t]{2}{*}{ Pelatihan } & Tidak Pernah & 17 & 70,8 \\
\hline & Pernah & 7 & 29,2 \\
\hline \multirow[t]{2}{*}{ Lama Kerja } & $\leq 5$ tahun & 15 & 62,5 \\
\hline & $>5$ tahun & 9 & 37,5 \\
\hline \multicolumn{4}{|c|}{ Kompetensi Responden $(\mathrm{n}=24)$} \\
\hline \multirow[t]{2}{*}{ Pengetahuan } & Kurang & 23 & 95,8 \\
\hline & Baik & 1 & 4,2 \\
\hline \multirow[t]{2}{*}{ Sikap } & Unfavorable & 11 & 45,8 \\
\hline & Favorable & 13 & 54,2 \\
\hline \multirow[t]{2}{*}{ Keterampilan } & Kurang & 12 & 50 \\
\hline & Baik & 12 & 50 \\
\hline \multicolumn{4}{|c|}{ Pendapat Fungsi Perencanaan $(n=24)$} \\
\hline \multirow[t]{2}{*}{ Pengorganisasian } & Kurang & 11 & 45,8 \\
\hline & Baik & 13 & 54,2 \\
\hline Penggerakan/ & Kurang & 12 & 50 \\
\hline \multirow{3}{*}{$\begin{array}{l}\text { Pelaksanaan } \\
\text { Pengendalian }\end{array}$} & Baik & 12 & 50 \\
\hline & Kurang & 12 & 50 \\
\hline & Baik & 12 & 50 \\
\hline Pelaksanaan & Kurang & 11 & 45,8 \\
\hline Kegiatan & Baik & 13 & 54,2 \\
\hline \multicolumn{4}{|c|}{ Perkesmas } \\
\hline \multicolumn{4}{|c|}{ Keberhasilan Upaya Perkesmas $(n=20)$} \\
\hline Ketersediaan & Kurang & 20 & 100 \\
\hline Input & Baik & 0 & 0 \\
\hline \multirow[t]{2}{*}{ Tingkat Proses } & Kurang & 17 & 85 \\
\hline & Baik & 3 & 15 \\
\hline Luaran/Hasil & Kurang & 18 & 90 \\
\hline (Output) & Baik & 2 & 10 \\
\hline
\end{tabular}

Hasil analisis pada tabel 1. menunjukkan bahwa lebih dari sebagian $(58,3 \%)$ responden berumur $\leq 30$ tahun, sebagian besar $(83,3 \%)$ berjenis kelamin perempuan, lebih dari sebagian $(54,2 \%)$ dengan pendidikan DIII Keperawatan, sebagian besar $(70,8 \%)$ belum pernah mengikuti pelatihan perkesmas, dan lebih dari sebagian $(62,5 \%)$ responden dengan lama kerja $\leq 5$ tahun.

Hasil analisis keberhasilan upaya perkesmas menunjukkan seluruh (100\%) Puskes-mas dengan ketersedian input dengan kategori kurang, sebagian besar $(85 \%)$ Puskesmas mempunyai pemenuhan indikator proses dengan kategori kurang, dan hampir se- 
luruh (90\%) Puskesmas mempunyai pemenuhan indikator luaran/hasil dengan kategori kurang.

Hasil analisis kompetensi responden pada penelitian ini menunjukkan bahwa hampir seluruh $(95,8 \%)$ responden dengan pengetahuan kurang, hampir sebagian $(45,8 \%)$ dengan sikap Unfavorable dan sebagian (50\%) responden dengan keterampilan kurang.

Hasil analisis menunjukkan bahwa hampir sebagian $(45,8 \%)$ responden berpendapat fungsi pengorganisasian Puskesmas dengan kategori kurang, sebagian $(50 \%)$ berpendapat fungsi penggerakan/pelaksanaan dengan kategori kurang, dan sebagian $(50 \%)$ reponden menyatakan pelaksanaan fungsi pengendalian puskesmas adalah kurang.

Hasil analisis tentang pendapat responden tentang pelaksanaan kegiatan perkesmas di Puskesmas Kota Bengkulu menunjukkan bahwa hampir sebagian $(45,8 \%)$ responden menyatakan pelaksanaan perkesmas di Puskesmas dengan kategori kurang.

Tabel 2. Distribusi Responden Berdasarkan Pendapat tentang Fungsi Perencanaan

\begin{tabular}{cccccc}
\hline Variabel & N & $\begin{array}{c}\text { Mean } \\
\text { Median }\end{array}$ & SD & $\begin{array}{c}\text { Min- 95\% CI } \\
\text { Mak for Mean }\end{array}$ \\
\hline Perencanaan & 24 & $\begin{array}{r}5,83 \\
6,00\end{array}$ & 2,353 & $1-9$ & $4,84-6,83$ \\
\hline
\end{tabular}

Hasil analisis pada tabel 2 penerapan fungsi manajemen SDM pada penelitian ini menunjukkan bahwa rata-rata pendapat responden tentang fungsi perencanaan di Puskes-mas adalah 5,83 sudah diatas nilai tengah skor fungsi perencaanan yang dapat dicapai yaitu sebesar 4,5. Dari hasil estimasi interval disimpulkan bahwa $95 \%$ diyakini rata-rata pendapat responden tentang fungsi perencaaan adalah antara 4,84-6,83.

Hasil analisis pada tabel 3. menunjukkan bahwa dari 17 orang responden yang tidak pernah mengikuti pelatihan perkesmas terdapat 8 orang $(47,1 \%)$ dengan pelaksanaan kegiatan perkesmas kurang, sedangkan dari 7 orang responden yang pernah mengikuti pelatihan perkesmas terdapat 3 orang $(43,9 \%)$ dengan pelaksanaan kegiatan perkesmas kurang. Hasil analisis fisher exact test menunjukkan bahwa nilai $\mathrm{p}=1,000>\alpha=5 \%$, berarti tidak terdapat hubungan yang bermakna antara pelatihan dengan pelaksanaan kegiatan perkesmas di Puskesmas.

Tabel 3. Hubungan karakteristik responden dengan pelaksanaan perkesmas

\begin{tabular}{|c|c|c|c|c|c|c|c|}
\hline \multirow{3}{*}{ Variabel } & \multicolumn{6}{|c|}{$\begin{array}{c}\text { Pelaksanaan Kegiatan } \\
\text { Perkesmas } \\
\end{array}$} & \multirow{3}{*}{ Nilai p } \\
\hline & \multicolumn{2}{|c|}{ Kurang } & \multicolumn{2}{|c|}{ Baik } & \multicolumn{2}{|c|}{ Jumlah } & \\
\hline & $\mathbf{f}$ & $\%$ & $\mathbf{f}$ & $\%$ & $\mathbf{f}$ & $\%$ & \\
\hline \multicolumn{8}{|l|}{ Pelatihan } \\
\hline Tidak Pernah & 8 & 47,1 & 9 & 52,9 & 17 & 100 & 1,000 \\
\hline Pernah & 3 & 43,9 & 4 & 57,1 & 7 & 100 & \\
\hline \multicolumn{8}{|l|}{ Pengetahuan } \\
\hline Kurang & 11 & 47,8 & 12 & 52,2 & 23 & 100 & 1,000 \\
\hline Baik & 0 & 0 & 1 & 100 & 1 & 100 & \\
\hline \multicolumn{8}{|l|}{ Sikap } \\
\hline Unfavorable & 6 & 54,5 & 5 & 45,5 & 11 & 100 & 0,706 \\
\hline Favorable & 5 & 38,5 & 8 & 61,5 & 13 & 100 & \\
\hline Keteram-pilan & & & & & & & \\
\hline Kurang & 8 & 66,7 & 4 & 33,3 & 12 & 100 & 0,101 \\
\hline Baik & 3 & 25 & 9 & 75 & 12 & 100 & \\
\hline
\end{tabular}

Hasil analisis tabel 3 juga menunjukkan bahwa dari 23 orang responden dengan pengetahuan kurang ada 11 orang (47,8\%) dengan pelaksana-an kegiatan perkesmas kurang, sedangkan dari 1 orang responden dengan pengetahuan baik, tidak ada pelaksanaan kegiatan perkesmas kurang. Hasil uji fisher exact test menunjukkan bahwa nilai $p=1,000>\alpha=5 \%$, berarti tidak terdapat hubungan yang bermakna antara pengetahuan dengan pelaksanaan kegiatan perkesmas di Puskesmas.

Hasil analisis menunjukkan bahwa dari 11 orang responden dengan sikap unfavorable ada 6 orang $(54,5 \%)$ dengan pelaksanaan kegiatan perkesmas kurang, sedangkan dari 13 orang responden dengan sikap favorable ada 5 orang $(38,5 \%)$ dengan pelaksanaan kegiatan perkesmas kurang. Hasil uji chi-square menunjukkan bahwa nilai $\mathrm{p}=0,706>\alpha=5 \%$, berarti tidak terdapat hubungan yang bermakna antara sikap dengan pelaksanaan kegiatan perkesmas di Puskesmas.

Hasil analisis menunjukkan bahwa dari 12 orang responden dengan keterampilan kurang ada 8 orang $(66,7 \%)$ dengan pelaksanaan kegiatan perkesmas kurang, sedangkan dari 12 
orang responden dengan keterampilan baik ada 3 orang (25\%) dengan pelaksanaan kegiatan perkesmas kurang. Hasil uji chisquare menunjukkan bahwa nilai $\mathrm{p}=0,101>\alpha=5 \%$, berarti tidak terdapat hubungan yang bermak-na antara keterampilan dengan pelaksanaan kegiatan perkesmas di Puskesmas.

Tabel 4. Hubungan Perencanaan dengan Pelaksanaan Kegiatan Perkesmas di Puskesmas Kota Bengkulu

\begin{tabular}{cccc}
\hline Variabel & $\mathbf{r}$ & $\mathbf{R}^{\mathbf{2}}$ & $\boldsymbol{p}$ value \\
\hline Perencanaan & 0,456 & 0,208 & 0,025 \\
\hline
\end{tabular}

Hasil analisis tabel 4. didapatkan hubungan antara fungsi perencanaan dengan pelaksanaan kegiatan perkesmas menunjukkan hubungan sedang $(\mathrm{r}=0,456)$ dan berpola positif artinya semakin tinggi skore fungsi perencaaan semakin tinggi skore pelaksanaan kegiatan perkesmas. Hasil uji statistik juga menunjukkan ada hubungan yang signifikan antara fungsi perencanaan dengan pelaksanaan kegiatan perkesmas $(\mathrm{p}=0,025)$.

Tabel 5. Hubungan Pengorganisasian, Penggerakan, dan Pengendalian dengan Pelaksanaan Kegiatan Perkesmas di Puskesmas Kota Bengkulu

\begin{tabular}{|c|c|c|c|c|c|c|c|}
\hline \multirow{4}{*}{ Variabel } & \multicolumn{6}{|c|}{ Pelaksanaan Kegiatan } & \multirow{4}{*}{$\begin{array}{c}\text { Nilai } \\
\mathbf{p}\end{array}$} \\
\hline & \multicolumn{6}{|c|}{ Perkesmas } & \\
\hline & \multicolumn{2}{|c|}{ Kurang } & \multicolumn{2}{|c|}{ Baik } & \multicolumn{2}{|c|}{ Jumlah } & \\
\hline & $\mathbf{f}$ & $\%$ & f & $\%$ & $\mathbf{f}$ & $\%$ & \\
\hline \multicolumn{8}{|c|}{ Pengorganisasian } \\
\hline Kurang & 7 & 63,3 & 4 & 36,4 & 11 & 100 & \multirow[t]{2}{*}{0,231} \\
\hline Baik & 4 & 30,8 & 9 & 69,2 & 13 & 100 & \\
\hline \multicolumn{8}{|l|}{ Penggerakan } \\
\hline Kurang & 8 & 66,7 & 4 & 33,3 & 12 & 100 & \multirow[t]{2}{*}{0,101} \\
\hline Baik & 3 & 25 & 9 & 75 & 12 & 100 & \\
\hline \multicolumn{8}{|l|}{ Pengendalian } \\
\hline Unfavorable & 9 & 75 & 3 & 25 & 12 & 100 & \multirow[t]{2}{*}{0,014} \\
\hline Favorable & 2 & 16,7 & 10 & 83,3 & 12 & 100 & \\
\hline
\end{tabular}

Hasil analisis tabel 5 menunjukkan bahwa dari 11 orang responden yang menyatakan penerapan fungsi pengorganisasian kurang, ada 7 orang $(63,3 \%)$ dengan pelaksanaan kegiatan perkesmas kurang, sedangkan dari 13 orang responden yang menyatakan penerapan fungsi pengorganisasian baik, ada 4 orang $(30,8 \%)$ dengan pelaksanaan kegiatan perkesmas kurang. Hasil analisis uji chi- square menunjukkan bahwa nilai $p=0,231>\alpha=5 \%$, berarti tidak terdapat hubungan yang bermak-na antara penerapan fungsi pengorganisasian dengan pelaksanaan kegiatan perkesmas di Puskesmas.

Hasil analisis menunjukkan bahwa dari 12 orang responden yang menyatakan penerapan fungsi penggerakan kurang, ada 8 orang $(66,7 \%)$ dengan pelaksanaan kegiatan perkesmas kurang, sedangkan dari 12 orang responden yang menyatakan penerapan fungsi penggerakan baik, ada 3 orang $(25 \%)$ dengan pelaksanaan kegiatan perkesmas kurang. Hasil analisis uji chi-square menunjukkan bahwa nilai $\mathrm{p}=0,101>\alpha=5 \%$, berarti tidak terdapat hubungan yang bermakna antara penerapan fungsi penggerakan dengan pelaksanaan kegiatan perkesmas di Puskesmas.

Hasil analisis tabel menunjukkan bahwa dari 12 orang responden yang menyatakan penerapan fungsi Pengendalian kurang, ada 9 orang $(75 \%)$ dengan pelaksanaan kegiatan perkesmas kurang, sedangkan dari 12 orang responden yang menyatakan penerapan fungsi Pengendalian baik, ada 2 orang $(16,7 \%)$ dengan pelaksanaan kegiatan perkesmas kurang. Hasil analisis uji chi-square menunjukkan bahwa nilai $\mathrm{p}=0,014<\alpha=5 \%$, berarti ada hubungan yang bermakna antara penerapan fungsi Pengendalian dengan pelaksanaan kegiatan perkesmas di Puskesmas.

\section{PEMBAHASAN}

\section{Pelaksanaan Kegiatan Perkesmas di Pus- kesmas Kota Bengkulu}

Hasil penelitian menunjukkan bahwa seluruh (100\%) Puskesmas dengan ketersedian input dengan kategori kurang, sebagian besar (85\%) Puskesmas mempunyai pemenuhan indikator proses dengan kategori kurang, dan hampir seluruh (90\%) Puskesmas mempunyai pemenuhan indikator luaran/hasil dengan kategori kurang. Hasil penelitian juga menunjukkan bahwa hampir sebagian $(45,8 \%)$ perawat pengelola perkesmas menyatakan pelaksanaan perkesmas di Puskesmas dengan kategori kurang. 
Hasil tersebut menunjukkan bahwa keberhasilan upaya Keperawatan Kesehatan Masyarakat di Puskesmas Kota Bengkulu berdasarkan indikator masukan (input), indikator proses, dan indikator luaran (output) masih jauh dibawah indikator yang ditetapkan oleh kementerian kesehatan. Untuk indikator input sebagian besar (80\%) Puskesmas tidak mempunyai minimal 1 kit untuk setiap desa untuk melaksanakan kegiatan perkesmas dan sebagian besar (85\%) Puskesmas tidak mempunyai ruangan khusus untuk asuhan keperawatan di Puskesmas. Untuk Indikator proses, sebagian besar (85\%) Puskesmas tidak mempunyai rencana peningkatan pendidikan/pelatihan perawat secara berkelanjutan dan lebih dari separuh (60\%) Puskesmas dengan kegiatan perkesmas yang tidak didukung dan dibimbing oleh kepala Puskesmas. Pada indikator output, hampir seluruh Puskesmas (90\%) dengan persentase pasien yang dilakukan asuhan keperawatan tidak sesuai standar dan sebagian besar $(70 \%)$ Puskesmas dengan persentase kelompok khusus (panti, rutan lapas, dll) yang dibina tidak sesuai standar.

Menurut Peneliti ada beberapa hal yang dapat menyebabkan belum baiknya pelaksanaan perkesmas di Puskesmas Kota Bengkulu, seperti adanya aturan baru yang dikeluarkan Dinkes Kota Bengkulu pada tahun 2014 bahwa pengelola perkesmas harus dengan latar belakang pendidikan perawat dengan pendidikan minimal D III Keperawatan, masih banyak pengelola perkesmas yang belum mengikuti pelatihan perkesmas dan belum mempunyai dana tersendiri untuk program perkesmas, dan lain-lain.

Hasil penelitian sejalan dengan penelitian Tafwidhah (2010) di Kota Pontianak yang menunjukkan kegiatan perkesmas kurang optimal sebesar 55,9\%. Demikian juga penelitian Ratnasari (2012) di Puskesmas Wilayah Kotamdya Jakarta Barat tahun 2010 menunjukkan hampir separuh $(43,7 \%)$ pelaksanaan perkesmas adalah tidak baik.

Penyelenggaraan Keperawatan Kesehatan Masyarakat di Puskesmas, di laksanakan secara bertahap sesuai dengan sum- berdaya yang dimiliki oleh Puskesmas. Strategi yang ditetapkan adalah (1) Perkesmas sebagai bagian integral upaya kesehatan Puskesmas baik upaya kesehatan wajib maupun pengembangan, (2) Perkesmas sebagai upaya kesehatan pengembangan.

\section{Hubungan Pelatihan dengan Pelaksanaan Kegiatan Perkesmas}

Hasil penelitian menunjukkan sebagian besar $(70,8 \%)$ belum pernah mengikuti pelatihan perkesmas. Hasil penelitian sejalan dengan penelitian Ratnasari (2012) yang menunjukkan lebih dari sebagian $(62,7 \%)$ perawat pengelola perkesmas tidak pernah mengikuti pelatihan perkesmas. Demikian juga dengan penelitian Tafwidhah (2010) menunjukkan lebih dari sebagian $(62,7 \%)$ pengelola perkesmas belum pernah mengikuti pelatihan perkesmas.

Penelitian juga menunjukkan bahwa tidak terdapat hubungan yang bermakna antara pelatihan dengan pelaksanaan kegiatan perkesmas di Puskesmas $(\mathrm{p}=1,000)$. Hasil penelitian tidak sejalan dengan penelitian di Puskesmas Wilayah Kotamdya Jakarta Barat tahun 2010 yang menunjukkan ada hubungan pelatihan perkesmas dengan tingkat keterlaksanaan perkesmas $(\mathrm{p}=0,000)$ Ratnasari (2012). Demikian Hasil penelitian Saefulloh (2009) di ruang rawat inap RSUD Indramayu menunjukkan adanya peningkatan pada motivasi dan kinerja perawat setelah mendapat pelatihan asuhan keperawatan.

Pada penelitian ini tidak ada hubungan antara pelatihan dengan pelaksanaan kegiatan perkesmas dapat disebabkan karena kekurangan tenaga perawat perkesmas yang ada di Puskesmas sehingga walaupun beberapa orang perawat telah mendapatkan pelatihan perkesmas namun tidak melaksanakan kegiatan perkesmas dengan baik. Hasil wawancara dengan beberapa petugas perkesmas menunjukkan bahwa kurangnya pelaksanaan kegiatan perkesmas diakibatkan karena kekurangan tenaga, dimana setiap Puskesmas seharusnya memiliki 1 orang perawat perkesmas setiap desa namun Puskesmas baru memiliki 1 
perawat perkesmas setiap kecamatan atau Puskesmas.

\section{Hubungan Kompetensi Pengelola Perkesmas dengan Pelaksanaan Kegiatan Perkesmas Pengetahuan}

Hasil penelitian menunjukkan bahwa hampir seluruh $(95,8 \%)$ pengelola perkesmas dengan pengetahuan kurang. Penelitian juga menunjukkan tidak terdapat hubungan yang bermakna antara keterampilan dengan pelaksanaan kegiatan perkesmas di Puskesmas $(\mathrm{p}=1,000)$. Hasil penelitian sejalan dengan penelitian Tafwidhah (2010) yang menunjukkan hampir sebagian $(43,2 \%)$ pengetahuan perawat pengelola perkesmas di Kota Pontianak kurang baik dan tidak ada hubungan antara pengetahuan dan tingkat keterlaksanaan kegiatan perkesmas $(\mathrm{p}=0,992)$.

Menurut Notoatmodjo (2010) pengetahuan merupakan hasil tahu setelah melakukan penginderaan terhadap suatu objek tertentu. Penginderaan terjadi melalui panca indera manusia, yaitu penglihatan, pendengaran, penciuman, rasa, dan raba. Sebagian besar pengetahuan diperoleh melalui mata dan telinga. Pengetahuan merupakan domain yang sangat penting untuk terbentuknya tindakan seseorang. Pengukuran pengetahuan dapat dilakukan dengan wawancara angket yang menanyakan tentang isi materi yang ingin diukur dari subjek penelitian.

Hasil ini dapat disebabkan karena hampir seluruh pengelola perkesmas adalah pengelola baru yang ditunjuk pada tahun bulan Januari 2014 sehingga belum dapat melaksanakan program perkesmas dengan baik. Di sam-ping itu sebagian besar perawat pengelola perkesmas belum pernah mengikuti pelatihan perkesmas sehingga belum paham dalam melaksanakan program perkesmas.

\section{Sikap}

Hasil penelitian menunjukkan bahwa hampir sebagian $(45,8 \%)$ pengelola perkesmas dengan sikap Unfavorable. Hasil penelitian sejalan dengan Tafwidhah (2010) bahwa $55,1 \%$ perawat perkesmas mempunyai sikap kurang baik.
Penelitian juga menunjukkan tidak terdapat hubungan yang bermakna antara sikap dengan pelaksanaan kegiatan perkesmas di Puskesmas $(p=0,706)$. Hasil penelitian tidak sejalan dengan penelitian Tafwidhah (2010) di Kota Pontianak, dimana terdapat hubungan antara sikap dan tingkat keterlaksanaan kegiatan perkesmas dengan $(\mathrm{p}=0,000)$.

Sikap (attitude) adalah pernyataan evaluatif yang mencerminkan bagaimana seseorang merasakan sesuatu baik yang menguntungkan atau tidak menguntungkan mengenai obyek, orang, atau peristiwa. Sikap yang berkaitan dengan pekerjaan membuka jalan evaluasi positif atau negatif mengenai aspek dari lingkungan kerja. Kebanyakan riset dalam perilaku individu mempedulikan tiga sikap yang berkaitan dengan kepuasan kerja, keterlibatan kerja, dan komitmen organisasi. Kepuasan kerja merujuk pada sikap umum seorang individu terhadap pekerjaannya. Tingkat kepuasan kerja yang tinggi menunjukkan sikap yang positif terhadap pekerjaan, begitu pula sebaliknya Robbins (2003).

Pada penelitian ini tidak ada hubungan antara sikap dengan pelaksanaan kegiatan perkesmas dapat disebabkan karena sebagian besar perawat menganggap program perkesmas sebagai upaya kesehatan pengembangan sehingga kurang diperhatikan. Hal ini tergambar dari hasil wawancara dengan beberapa perawat pengelola perkesmas, didapatkan data Puskesmas tidak mempunyai alokasi dana khusus, misalnya untuk pelatihan perkesmas dan bimbingan teknis. Kegiatan pelatihan akan diikuti perawat apabila ada panggilan pelatihan dari Dinkes Kota/Propinsi Bengkulu. Demikian juga dengan kegiatan bimbingan teknis hanya bersifat insidentil apabila ada kasus/masalah yang harus ditindak lanjuti.

\section{Keterampilan}

Hasil penelitian menunjukkan bahwa sebagian $(50 \%)$ pengelola perkesmas dengan keterampilan kurang. Penelitian juga menunjukkan tidak terdapat hubungan yang bermakna antara keterampilan dengan pelaksanaan kegiatan perkesmas di Puskesmas $(\mathrm{p}=0,101)$. 
Hasil penelitian tidak sejalan dengan penelitian Tafwidhah (2010) yang menunjukkan separuh perawat $(49,2 \%)$ dengan keterampilan kurang baik, dan ada hubungan antara keterampilan perawat dengan tingkat keterlaksanaan kegiatan perkesmas $(\mathrm{p}=0,000)$.

Menurut Weldford (1968) dalam Winterton \& Stringfellow (2005) keterampilan (skill) merupakan hasil kombinasi faktorfaktor yaitu kompeten, keahlian, dan kinerja prima yang terlihat dari aktivitas fisik dan mental. Terdapat tiga tingkatan untuk memperoleh keterampilan yang baik, yaitu fase kognitif, fase asosiasi, dan fase bertindak. Fase kognitif adalah pemahaman suatu materi sehingga diketahui tindakan yang tepat untuk menyelesaikan masalah tersebut. Fase asosiasi melihat bagaimana hubungan dengan bagian lainnya dalam menentukan tindakan yang tepat serta mempertimbangkan keadaan untuk mengurangi gangguan yang datang dari luar. Terakhir, fase bertindak dengan mengambil langkah yang tepat.

Pada penelitian ini tidak ada hubungan antara keterampilan dengan pelaksanaan kegiatan perkesmas dapat disebabkan hampir seluruh perawat pengelola perkesmas baru mendapatkan tanggung jawab sebagai pengelola perkesmas sehingga keterampilan perawat tersebut setengahnya adalah kurang baik.

Hasil wawancara dengan petugas perkesmas juga menunjukkan Manajemen pengelolaan perkesmas yang kurang baik juga menyebabkan perawat cenderung mengabaikan pelaksanaan kegiatan perkesmas. Supervisi tidak pernah dilakukan oleh pimpinan terhadap pelaksanaan kegiatan perkesmas. Pendanaan khusus perkesmas yang tidak terdapat dalam POK Puskesmas juga menjadi penyebab pelaksanaan kegiatan perkesmas jalan di tempat. Pendanaan belum diberikan alokasi tersendiri, masih tergabung dengan upaya pokok Puskesmas yang lain, misalnya kalau ada kasus gizi buruk maka dana yang dipakai adalah dana BOK Gizi, bila ada kasus TB Paru maka yang dipakai adalah dana dari program TB Paru.

\section{Hubungan Penerapan Fungsi Manajemen SDM dengan Pelaksanaan Kegiatan Perkesmas Penerapan Fungsi Perencanaan}

Hasil penelitian menunjukkan bahwa rata-rata pendapat responden tentang fungsi perencanaan di Puskesmas adalah 5,83 sudah diatas nilai tengah skor fungsi perencaanan yang dapat dicapai yaitu sebesar 4,5. Penelitian juga menunjukkan ada hubungan yang signifikan antara fungsi perencanaan dengan pelaksanaan kegiatan perkesmas $(\mathrm{p}=0,025)$.

Hasil penelitian sejalan dengan penelitian Ratnasari (2012) di Puskesmas Wilayah Kotamdya Jakarta Barat yang menyatakan bahwa lebih dari separuh $(54,9 \%)$ penerapan fungsi perencanaan adalah baik dan ada hubungan antara fungsi perencanaan SDM dengan pelaksanaan perkesmas di Puskesmas $(\mathrm{p}=0,016)$. Demikian juga dengan hasil penelitian Hernadi (2005) di Dinkes Hulu Sungai Tengah menunjukkan bahwa terdapat hubungan yang signifikan antara fungsi manajemen perencanaan $(\mathrm{p}=0,016)$ dengan cakupan program perkesmas.

Hasil penelitian sejalan dengan penelitian Ratnasari (2012), yaitu perencanaan SDM merupakan awal dari serangkaian proses manajemen SDM hingga tercapainya hasil kegiatan. Hasil tersebut sangat dipengaruhi oleh kemampuan pengelola dalam melihat kelebihan serta kekurangan yang terdapat pada segala sesuatu yang berkaitan dengan SDM khususnya dalam hal pelaksanaan perkesmas.

\section{Penerapan Fungsi Pengorganisasian}

Hasil penelitian menunjukkan bahwa hampir sebagian $(45,8 \%)$ pengelola perkesmas berpendapat fungsi pengorganisasian Puskesmas dengan kategori kurang. Hasil penelitian sejalan dengan penelitian (Ratnasari, 2012) di Puskesmas Wilayah Kotamadya Jakarta Barat, bahwa hampir separuh $(49,3 \%)$ perawat pengelola perkesmas menyatakan pene-rapan fungsi pengorganisasian dengan kategori tidak baik. Demikian juga dengan penelitian Al Umah (2003) yang menunjukkan sebagian besar pengorganisasian perkesmas buruk dengan cakupan sebesar $27,27 \%$. 
Hasil penelitian juga menunjukkan tidak terdapat hubungan yang bermakna antara penerapan fungsi pengorganisasian dengan pelaksanaan kegiatan perkesmas di Puskesmas $(\mathrm{p}=0,231)$. Hasil penelitian tidak sejalan dengan hasil penelitian Hernadi (2005) yang menunjukkan bahwa terdapat hubungan yang signifikan antara fungsi manajemen pengorganisasian dengan $(\mathrm{p}=0,019)$ cakupan program perkesmas di Dinkes Hulu Sungai Tengah. Demikian Juga dengan penelitian Ratnasari (2012), bahwa fungsi pengorganisasian berhubungan dengan pelaksanaan perkesmas di Puskesmas ( $\mathrm{p}=0,024)$.

Menurut Suyanto (2009), pengorganisasian adalah pengaturan setelah ada rencana, yaitu pengaturan dan penentuan tentang apa tugas pekerjaan, macam/jenis serta sifat pekerjaan, unit-unit kerja, siapa yang akan melakukan, apa alatnya, bagaimana keuangannya, dan fasilitas-fasilitasnya. Kemudian setelah ada penentuan tersebut, diadakan pembagian tugas baik macam, sifat, atau jenis tugas pekerjaan, agar dapat dengan mudah diupayakan petugas yang cakap, mampu, dan terampil sesuai dengan persyaratan yang dibutuhkan.

\section{Penerapan Fungsi Penggerakan/pelaksanaan}

Hasil penelitian menunjukkan bahwa sebagian $(50 \%)$ pengelola perkesmas berpendapat fungsi penggerakan/pelaksanaan dengan kategori kurang. Penelitian juga menunjukkan tidak terdapat hubungan yang bermakna antara penerapan fungsi penggerakan/pelaksa-naan dengan pelaksanaan kegiatan perkesmas di Puskesmas $(\mathrm{p}=0,101)$. Hasil penelitian sejalan dengan penelitian Ratnasari (2012) di Puskesmas Wilayah Kotamdya Jakarta Barat, bahwa hampir separuh $(47,9 \%)$ perawat pengelola perkesmas menyatakan penerapan fungsi pelaksanaan/penggerakan dengan kategori tidak baik dan tidak ada hubungan antar penggerakan/pelaksanaan dengan pelaksanaan perkesmas di Puskesmas $(\mathrm{p}=0,131)$.

Hasil penelitian tidak sejalan dengan penelitian Hernadi (2005) di Dinkes Kabupaten hulu Sungai tengah yang menunjukkan bahwa terdapat hubungan yang signifikan an- tara fungsi manajemen pelaksanaan dengan cakupan program perkesmas di Dinkes Hulu Sungai Tengah $(\mathrm{p}=0,020)$.

Pada penelitian tidak ada hubungan antara penerapan fungsi penggerakan/pelaksanaan dengan pelaksanaan kegiatan perkesmas dapat disebabkan karena puskesmas tidak melaksanakan pengkajian terhadap rencangan pengembangan program perkesmas $(54,2 \%)$ dan tidak melaksanakan advokasi terhadap pimpinan dan sektor terkait dalam pelaksanaan perkesmas $(54,2 \%)$ sehingga walaupun ada sebagian $(50 \%)$ perawat perkesmas yang menyatakan penerapan fungsi penggerakan/pelaksanan dengan kategori baik namun pelaksanaan perkesmas di Puskesmas tersebut dengan kategori kurang baik.

\section{Penerapan Fungsi Pengendalian}

Hasil penelitian menunjukkan bahwa sebagian $(50 \%)$ pengelola perkesmas menyatakan penerapan fungsi pengendalian puskesmas adalah kurang. Penelitian menunjukkan ada hubungan yang bermakna antara penerapan fungsi Pengendalian dengan pelaksanaan kegiatan perkesmas di Puskesmas $(\mathrm{p}=0,014)$.

Hasil penelitian sejalan dengan penelitian Ratnasari (2012), bahwa hampir separuh $(47,9 \%)$ perawat pengelola perkesmas menyatakan penerapan fungsi pengendalian dengan kategori tidak baik dan ada hubungan antar pengendalian dengan pelaksanaan perkesmas di Puskesmas ( $\mathrm{p}=0,003)$. Demikian juga hasil penelitian Hernadi (2005) menunjukkan bahwa terdapat hubungan yang signifikan antara fungsi manajemen pengendalian dengan cakupan program perkesmas di Dinkes Hulu Sungai Tengah ( $\mathrm{p}=0,020)$.

Menurut Swansburg (2000), pengendalian adalah suatu fungsi manajemen yang dilakukan secara terus menerus selama perencanaan, pengorganisasian, pengelolaan staf, dan pengarahan aktivitas. Melalui proses ini standar dibuat dan kemudian digunakan dan diikuti umpan balik untuk perbaikan. Pengendalian berupa kebijakan, aturan, prosedur, kontrol diri, laporan, audit, alat-alat evaluasi, analisa tugas, dan kontrol kualitas. 


\section{KESIMPULAN}

Hasil penelitian disimpulkan bahwa hampir sebagian $(45,8 \%)$ perawat pengelola perkesmas menyatakan pelaksanaan perkesmas di Puskesmas dengan kategori kurang. Seluruh (100\%) Puskesmas dengan ketersedian input dengan kategori kurang, sebagian besar (85\%) Puskesmas mempunyai pemenuhan indikator proses dengan kategori kurang, dan hampir seluruh (90\%) Puskesmas mempunyai pemenuhan indikator luaran/hasil dengan kategori kurang. Ada hubungan yang bermakna antara fungsi perencanaan $(\mathrm{p}=0,025)$ dan pengendalian $(0,014)$ dengan

\section{DAFTAR RUJUKAN}

Al Umah, M.B., 2003. Evaluation On Implementation Community Health Nursing Of Home Care Visit In Community Health Center In The Kebumen Regency.

Depkes RI,. 2006. Pedoman Kegiatan Perawat Kesehatan Masyarakat di Puskesmas. Jakarta. Depkes RI

Dinkes Provinsi Bengkulu, 2014. Laporan Tahunan Program Perkesmas Tahun 2013. Bengkulu : Dinkes Propinsi Bengkulu

Hernadi, 2005. Fungsi Manajemen Koordinator Perkesmas Puskesmas yang berhubungan dengan Cakupan Program Perkesmas di Dinkes Kabupaten hulu Sungai tengah. http://lrckmpk.undip.ac.id. Diakses tanggal 15 Januari 2014.

Kemenkes RI, 2011. Laporan Implementasi Perkesmas Tahun 2011. Direktorat Bina Pelayanan Keperawatan dan Keteknisian Medik.

Notoatmodjo, S. 2010. Promosi Kesehatan dan Ilmu Prilaku. Jakarta : Rineka Cipta.

Nurhomah, 2013. Hubungan Motivasi Dan Pendidikan Kepala Keluarga Dengan Keaktifan Mengikuti Kegiatan Perkesmas Di Desa Imigrasi Permu Kabupaten Kepahiang Tahun 2013. Stikes Dehasen Bengkulu.

Ratnasari, M., 2012. Faktor-faktor Manajemen Sumber Daya Manusia yang Mempengaruhi Pelaksanaan perkkesmas di Puskesmas Wilayah Kotamdya Jakarta Barat tahun 2010. Program Studi Magister Ilmu Keperawatan Kekhususan Kepemimpinan dan Manajemen Keperawatan Fakultas Ilmu Keperawatan Indonesia.

Robbins, S.P. 2003. Perilaku Organisasi : konsep, kontroversi, aplikasi. Terjemahan. Jakarta : PT Prenhalindo.

Saefulloh, M. 2009. Pengeruh pelatihan asuhan pelaksanaan kegiatan perkesmas di Puskesmas Kota Bengkulu.

Disarankan kepada pihak Dinas Kesehatan Kota Bengkulu untuk melatih seluruh perawat pengelola perkesmas dan perawat yang akan dipersiapkan untuk membantu pengelolaan perkesmas, mewajibkan setiap Puskesmas di Kota Bengkulu untuk menambah jumlah perawat penanggung jawab perkesmas, minimal satu penanggung jawab untuk setiap desa di Kecamatan, melakukan pelatihan fungsi manajemen SDM bagi pimpinan Puskesmas agar dapat melakukan penerapan fungsi perencanaan dengan baik.

keperawatan dan supervisi terhadap motivasi kerja dan kinerja perawat pelaksana di ruang rawat inap RSUD Indramayu. Tesis. Depok: FIK UI. Tidak dipublikasikan.

Septino, T. \& Hasanbasri, M, 2007. Evaluasi Proses Pelaksanaan Perawatan Kesehatan Masyarakat di Puskesmas Kabupaten Lima Puluh Kota. Working Paper series No. 07. Yogyakarta : Program Magister Kebijakan dan Manajemen Pelayanan Kesehatan Universitas Gadjah Mada. http://pdfpath.com/Evaluasi-Proses-

Pelaksanaan-Perawatan-Kesehatan.html. Diakses tanggal 15 Januari 2014.

Suyanto, 2009. Mengenal kepemimpinan dan manajemen keperawatan di Rumah sakit. Yogyakarta. Mitra Cendekia

Swansburg, R.C. (2000). Pengantar kepemimpinan dan manajemen keperawatan untuk perawat klinis (Suharyati Samba, penerjemah). Jakarta: EGC.

Tafwidhah, Y., 2010. Hubungan Kompetensi perawat Puskesmas dan Tingkat Keterlaksanaan Kegiatan Perawatan Kesehatan Masyarakat (Perkesmas) di Kota Pontianak. Tesis. Program Studi Magister Ilmu Keperawatan Kekhususan Kepemimpinan dan Manajemen Keperawatan Fakultas Ilmu Keperawatan Indonesia.

Winterton, J. \& Stringfellow, E. 2005. Typology of knowledge, skills and competences: clarification of the concept and prototype. Centre for European Research on Employment and $\mathrm{Hu}$ man Resources Groupe ESC Toulouse. 1111.http://www.ecotec.com/europeaninventory/p ublications/method/CEDEFOP_typology.pdf. Diakses tanggal 15 Januari 2014. 